\title{
Rusya'da dilbilimsel çeviri kuramı: Temel yaklaşımlar ve kavramlar
}

\section{Olena KOZAN1}

\begin{abstract}
APA: Kozan, O. (2019). Rusya'da dilbilimsel çeviri kuramı: Temel yaklaşımlar ve kavramlar.
\end{abstract} RumeliDE Dil ve Edebiyat Araşttrmaları Dergisi, (15), 313-327. DOI: 10.2900o/rumelide.580620

\section{$\ddot{O} \mathbf{z}$}

Rusya'da çeviri olgusunun bilimsel terimlerle betimlendiği çalışmalar XX. yüzyılın ilk yarısında ortaya çıkmaya başlamıştır. Bu çalışmalarda çevirinin bir olgu olarak ele alınmasına rağmen çeviri bir 'sanat', çevirmen ise 'yeteneği olan bir kişi' olarak değerlendirilmiştir. İkinci Dünya Savaşı'ndan sonra çeşitli uluslararası örgütlerin kurulmasıyla yeniden şekillenen dünya düzeni Rusya'daki çeviri araştırmalarının yönünü değiştirmiştir. Savaş sonrası yeni nitelik kazanan uluslararası ilişkilerin sürdürülebilmesi için başta askeri, siyasi, diplomatik ve insani olmak üzere farklı alanlarda çalışabilecek ve iletişimi sağlayacak nitelikli çevirmenlere ihtiyaç duyulmuştur. Savaş sırasında ve savaş sonrası döneminde çeviri alanında tecrübe kazanan çevirmenler çeviri alanını geliştirmekle görevlendirilmiştir. İlk önce çevirmen kimliği ile tanınan bu araştırmacılar, dilbilimdeki gelişmeleri yakından takip etmiş ve çeviri olgusuna yönelik dilbilim çerçevesinde yaklaşımlar geliştirmiştir. Bu anlamda Rusya'daki çeviri kuramında çeviri olgusuna yönelik yapısal, işlevsel, anlamsal, göstergebilimsel yaklaşımların uygulandığı farklı kuramsal eğilimler görülebilir. Bu çalışmada 1950'li yllardan itibaren Y. İ. Retsker, V. G. Gak, A. D. Şveytser, A. S. Barhudarov, R. K. Minyar-Beloruçev, V. N. Komissarov gibi çevirmenlerin ve çeviribilimcilerin çalışmalarıyla ismini duyuran Rus çeviri ekolünde geliştirilen çeviri olgusuna yönelik yaklaşımlar ve kavramlar tanıtılmıştır. Çalışmanın kapsamının izin verdiği kadarıyla Türkiye'deki bazı çalışmalarda ismi geçen A. V. Fedorov’un yaklaşımı ile ilgili yeni bilgiler verilmiştir. Sayfa sayısı sınırlılığından dolayı bu çalışmada kuramsal bilgiler üzerinde durulmuş, Rusça - Türkçe dil çiftindeki örneklere bazı kavramların açıklanmasında başvurulmuştur.

Anahtar kelimeler: Çeviribilim, dilbilimsel çeviri kuramı, Rusça-Türkçe çeviri.

\section{Linguistic theory of translation in Russia: Major approaches and concepts}

\begin{abstract}
The first works in which the phenomenon of translation was described in scientific terms started to appear in the first part of the $2 \mathrm{O}^{\text {th }}$ century. Although the translation was dealt with as "a phenomenon" in these works, the translation itself was described as "an art" and a translator as "a gifted person". The Second World War and a new post-war world order changed the direction of translation studies in Russia. The need for the professional translators ensuring effective communication and capable of working in various areas such as military, political, diplomatic, humanitarian arose after the War in order to maintain international relations of a new quality. Specialists with experience in translation gained during and after the War were entrusted with a task of developing translation studies. These researchers known first of all as translators followed the trends in linguistics and developed the approaches toward the translation within the linguistics. Thus there are various theoretical trends
\end{abstract}

1 Öğr. Gör. Dr., Ankara Hacı Bayram Veli Üniversitesi, Edebiyat Fakültesi, Rus Dili ve Edebiyatı Bölümü (Ankara, Türkiye), olena.kozan@gmail.com, ORCID ID: 00oo-0002-7956-4567 [Makale kayıt tarihi: 11.05.2019-kabul tarihi: 16.06.2019; DOI: $10.29000 /$ rumelide.580620] 


\begin{abstract}
based on structural, functional, semantic and semiotic approaches toward the translation in the framework of translation theory in Russia. This article introduces the approaches and concepts developed by the Russian School of translation since 1950's in the works of Y. Retsker, V. Gak, A. Shveitser, A. Barhudarov, R. Minyar-Beloruchev, V. Komissarov. New facts about A. Fedorov's approach that is quoted in some works in Turkey were given within the scope of this work. Due to the page limit in this article theory was highlighted and a few examples from the Russian-Turkish language pair were provided to explain some of the concepts.
\end{abstract}

Keywords: Translation studies, linguistic translation theory, Russian - Turkish translation.

\title{
1. Giriş
}

Rusya'da çeviribilimin gelişimi Batı'daki çeviribilim ekollerinin gelişim aşamalarından farklılık göstermektedir. Avusturyalı çeviribilimci E. Prunč, Batı'da ve Rusya'da çeviribilimin gelişmesini karşlaştırırken şu metaforlara başvurmaktadır:

"Bati'da ve Rusya'da çeviribilimin gelişmesini karşılaştırırsak ilk olanı, karşıtsal dilbilim kaynağından kopmuş ve birbirine yakın olan karşllaştırmah edebiyatbilim, kültürbilim, etik, sosyal bilimler vadilerinden (...) geçmektedir. Rus çeviribilim ekolü daha çok filoloji nehrinin akımı olarak görünmekte, sözlü çevirinin ele alındiğı alan ise, psikoloji yatağındaki bir trmak olarak karşımıza çıkmaktadır." (2015, s. 9).

Araştırmacının belirttiği gibi Rusya'daki çeviribilim dilbilimsel çeviri kuramı bazında şekillenmiştir. Çeviri olgusu üzerinde çalışan araştırmacılar dilbilimdeki gelişmeleri yakından takip edip çeviriye yönelik farklı yaklaşımlar geliştirmiştir.

Rusya'da çeviri olgusunun ilk defa bilimsel terimlerle betimlendiği çalışmalar XX. yüzyılın ilk çeyreğinde ortaya çıkmaya başlamıştır. İlk betimlemelerin ortaya çıkışını 1917 Ekim Devrimi'nin sonucunda meydana gelen sosyo-kültürel değişiklikler belirlemiştir. Rusya İmparatorluğu yerine kurulan yeni devletin yerel edebiyattan ve yeni ideolojinin desteklendiği çevirilerden beslenmesi gerekiyordu. Bu anlamda Sovyet Dönemi'nin ilk yılları çeviri etkinlikleri için verimlidir. Rus yazar M. Gorki'nin çabalarıyla 1919 yılında dünya edebiyatının eserlerini Rusçaya kazandıracak olan Vsemirnaya literatura (Dünya Edebiyatı) yayınevi kurulmuştur. Bu yayınevinin başlıca amacı okurlara farklı milletlerin edebiyatlarının ortaya çıkışı ve gelişimi, şiir ve düz yazı sanatının gelişimi, milli edebiyatlar arasındaki etkileşim ile ilgili ayrıntılı bilgilerin verilmesiydi (Nelyubin, Huhuni, 2003, s. 110). Yayınevinin amaçları doğrultusunda XIX. yüzyıl boyunca gerçekleştirilen yoğun edebi çeviri etkinliklerinin sonucunda edebi çeviri alanında oluşmuş öznel 'estetik' anlayışından ayrılarak çeviri olgusuna yönelik nesnel yaklaşımların geliştirilmesi gerekiyordu. Dönemin tanıkları çeviriye yönelik yaklaşımların, çeviri ilkelerinin kimi çevirmenler tarafından sezgisel olarak hissedildiğini, ancak sözel ya da yazılı bir biçimde o güne kadar ele alınmadığını dile getirirler. Ayrıca Rus yazar ve çevirmen K. Çukovski "O zaman çeviri kuramın ele alan Rusça kitap yoktu (...) önceki dönemlerin yazarlarmmn bize, nadir yorumlar hariç edebi çeviriye yönelik genel çeviri ilkelerini birakmamalarna inanmak zor" diye bir yorumda bulunur (Nelyubin, Huhuni 2003, s. 111). Çevirinin ne olduğu, ne olması gerektiği gibi soruların ele alındığı ilk çalışma olarak 1919 yılında yayımlanan ve K. Çukovski'nin Perevod prozaiçeskiy (Düz Yazı Çevirisi) ve Rus şair N. Gumilev'in Perevod stihotvornıy (Şiir Çevirisi) başlıklı iki makaleyi içeren Printsıpı hudojestvennogo perevoda (Edebi Çevirinin İlkeleri) kabul edilmektedir. Ancak bu çalışmada, çevirinin bir olgu olarak ele alınmasına rağmen çeviri 'sanat', çevirmen ise 'yeteneği olan bir kişi’ olarak değerlendirilmiştir (Çukovski, 1919, s. 8). Daha sonraki yıllarda çeviriye yönelik 
yaklaşımın edebi çeviriler üzerinde nesnel olmayan kavramlarla geliştirilimesi devam etmiştir (Kozan, 2017, s. 316).

İkinci Dünya Savaşı'ndan sonra çeşitli uluslararası örgütlerin kurulmasıyla yeniden şekillenen dünya düzeni Rusya'daki çeviri araştırmalarının yönünü değiştirmiştir. Savaş sonrası yeni nitelik kazanan uluslararası ilişkilerin sürdürülebilmesi için askeri, siyasi, diplomatik, insani başta olmak üzere farklı alanlarda çalışabilecek ve iletişimi sağlayacak nitelikli çevirmenlere ihtiyaç duyulmuştur. Savaş sırasında ve savaş sonrası döneminde çeviri alanında tecrübe kazanan çevirmenler çeviri alanını geliştirmekle ve çeviri uzmanlarını yetiştirmekle görevlendirilmiştir. Artık yazarlar ve şairler değil, uzman çevirmenler aldıkları filoloji eğitimine ve kendi deneyimlerine dayanarak çeviri olgusuna bilimsel yaklaşımları belirlemeye başlamıştır. Çevirmen kimliği ile tanınan bu araştırmacılar dilbilimdeki gelişmeleri yakından takip etmiş ve çeviri olgusuna yönelik dilbilim çerçevesinde yaklaşımları geliştirmiştir. Bu açıdan 1950'li yıllardan itibaren çeviriye yönelik geliştirilen yaklaşımlar, dilbilimin geçtiği gelişme aşamalarına bağlı olarak sınıflandırılabilir. Söz konusu yaklaşımlar bu çalışmada yapısal, işlevsel, göstergebilimsel olarak sınıflandırılmıştır. Bazı yaklaşımlar çeviri sürecindeki tek bir sorun üzerinde yoğunlaştığı için ayrı bir başlık altında ele alınmıştır.

\section{2. Çeviri Karşılıkları Kuramı: Y. İ. Retsker}

Yakov İosifoviç Retsker'in 1950 yllında yayımlanan Teoriya i metodika uçebnogo perevoda (Çeviri Eğitiminde Kuram ve Yöntem) adlı makale derlemesindeki $O$ zakonomernı sootvetstviyah pri perevode na rodnoy yazık (Ana Diline Çeviri Sürecinde Tekrarlanan Karşllıklar Üzerine) başlıklı makalesi birçok araştırmacı tarafından Rusya'da dilbilimsel çeviri kuramının temellerinin atıldığı çalışma olarak kabul edilmektedir (Komissarov, 2002, s. 9). Bu makalede çevirinin dilbilimsel çözümlemenin konusu olabileceği, farklı çevirmenler tarafından çevrilmiş metinlerde tekrarlanan çeviri karşılıklarının bulunabildiği fikri ileri sürülmüştür. Dahası, bu çeviri karşlıklarının farklı metin türleri ve farklı dil çiftleri için geçerli olduğu dile getirilmiştir. Böylece, karşılaştırmalı dil araştırmalarının önemi ve dilbilimsel yaklaşımın önceliği vurgulanmıştır (Retsker, 2010, s. 10).

Retsker, çeviri sürecinde ortaya çıkan ve metnin türüne veya dile bağlı olmaksızın herhangi bir dil çiftinde tekrarlanabilen "çeviri karşılıkları" kavramını ileri sürmüştür. Çeviri karşılıkları sınıflandırmasında üç tür karşılık gösterilmiştir. Birinci grupta sabit eşdeğerler yer almıştır. Eşdeğerlik, bağlama bağlı olmayan sabit ve tek anlamlı karşllık olarak tanımlanmıştır (Retsker, 2010, s. 13). Örnek olarak coğrafi terimler, özel isimler, siyasi terimler gösterilmiştir. İkinci grubu "eş anlamlı" birimler oluşturmuştur. $\mathrm{Bu}$ birimler bağlama ve metne bağlı olan sözcükler, deyimler ve yapılar olarak nitelenmiştir. Kaynak metindeki birimin hedef dilde birkaç karşılığı olabileceğinden çevirmenin, seçimini bağlama göre yaptığı dile getirilmiş ve eş anlamlı birimler kavramı tanıtılmıştır. Üçüncü gruba "karşllıksızlıklar" dahil edilmiştir. Değişken birimler olarak tanımlanabilen "amaca uygun değiştirmeler" kavramı ileri sürülmüştür (Komissarov, 2002, s. 11). Çevirmenin, karşllğ̆ı olmayan bir birimle karşlaştığında metnin içeriğine, türüne, üslubuna göre amaca uygun değiştirmeler yapabileceği dile getirilmiştir. Retsker, amaca uygun değiştirmeler için dört çeviri stratejisini ileri sürer. Ayrıca, somutlaştırma; mantıksal çıkarım; karşıt anlamlı çeviri; telâfi şeklinde çeviri stratejisi tanıtılmıştır.

Retsker, çevirmenin zihinsel sözlüğünde ilk önce sabit eşdeğerlerin oluştuğu, ikinci aşamada eş anlamlı birimlerin tanıma ve seçme sürecinin gerçekleştiği, son olarak da amaca uygun değiştirmelerin kullanılmaya başladığına dair düşünceleri ileri sürmüştür. Bu varsayımdan yola çıkarak Retsker, çeviri eğitiminin ilk aşamasında sabit eşdeğerlerin öğretilmesi, ikinci aşamada eş anlamlı birimlerin 
bulunmasına yönelik alıştırmaların yapılması ve üçüncü aşamada ise metinler arası amaca uygun değiştirmelerin gösterilmesi gerektiğini vurgulamıştır.

Bazı araştırmacılar Retsker'in sınıflandırma denemesinin kapsamlı olmadığını dile getirmektedir (Komissarov, 2002, s. 10). Buna rağmen Retsker’in betimlemesi çeviri karşılıkları kuramında ilk deneme niteliğindeydi. Retsker, çeviri kuramı üzerinde hayatı boyunca çalışmış ve geliştirmeye çaba göstermiştir. 1974 yllında yayımlanan Teoriya perevoda i perevodçeskaya praktika (Çeviri Kuramı ve Uygulamaları) adlı kitabında Retsker’in, çeviri karşılıklarına yönelik sınıflandırmayı geliştirdiği, sözcüksel ve dilbilgisel dönüşümler kavramı üzerinde durduğu, çeviride kiplik konusunu ele aldığı görülebilir.

\section{3. Çeviri Kuramına Giriş: A.V. Fedorov}

Andrey Venediktoviç Fedorov'un 1953 yllında yayımlanan Vvedeniye $v$ teoriyu perevoda (Çeviri Kuramına Giriş) kitabı Rusya'da çevirinin dilbilimsel sorunlarını gündeme getirmiştir. Komissarov'un yazdığı gibi:

"Fedorov'un kitabı dilbilimsel çeviribilimin gelisstirilmesinin gereksinimini dile getiren manifesto niteliğindeydi. (...) Retsker’in makalesi akademik çevre tarafindan dikkate alınmamış, Fedorov'un kitabı ise, Rusya’da çevirinin dilbilimsel yönünün tartışılmasına yol açmıştır." (2002, s. 25).

Fedorov çeviriyi kaynak metne, dil çiftinin özelliklerine ve metnin türüne bağlı olan, söz eyleminde ortaya çıkan bir oluşum olarak değerlendirmektedir (2002, s. 14). Ona göre çevirinin sınırları, çeviride kullanılabilecek dil araçları, çeviri stratejileri ve değişmezleri bu kriterlere göre belirlenmektedir. Görüldüğü gibi Fedorov'un yaklaşımında çeviri farklı kriterlere göre değişebilen ve bu anlamda esnek bir kavramdır. Çeviriye yönelik bu yaklaşım Fedorov'un geliştirdiği çeviri kuramını da şekillendirmiştir.

Fedorov'a göre çeviri kuramının amacı kaynak ile hedef metin arasındaki değişken unsurların ve değişmezlerin belirlenmesi, mevcut çevirilerden yola çıkarak elde edilen verilerin bilimsel kriterlere göre değerlendirilmesi ve genellemelerin yapılmasıdır. Fedorov, çeviri kuramının kuralcı değil, verileri genelleyen ve sınıflandıran bir kuramın olması gerektiğini de vurgulamıştır. "Çeviri kuramının, çeviride olması gerekenlere değil, mevcut verilere odaklanması gerekir." (2002, s. 19).

Fedorov çevirinin dil boyutunda gerçekleştiği için çeviri kuramının dilbilimsel bir disiplin niteliği taşıması gerektiğini ileri sürmüştür. Bunun yanı sıra araştırmacı, çeviri kuramının "tarif kitabı" olmadığını dile getirerek, "Çeviri kuramı çeviri sürecinde ortaya çıkan verileri çözümler, açıklar ve sinıflandırır; diller arası benzerlik ve farklılıkları belirler. Çeviri kuramı çeviri uygulamaları için bilimsel bir dayanak sağlamaktadır" biçiminde yorumda bulunmaktadır (2002, s. 23).

Fedorov'un diğer bir önemli yorumu diller arasındaki benzerlikler ve çeviri yöntemleri ile ilgilidir: "İki dil arasındaki benzerliklerin veya yakın çeviri karşılıklarını olması her zaman ayn çeviri yöntemlerinin kullanımın gerektirmez. Bağlam her zaman belirleyici bir unsur olacaktır" (2002, s. 23). Görüldüğü gibi burada da çevirinin esnek ve değişken bir olgu olduğu vurgulanmakta ve çeviri kuramının bu kritere göre geliştirilmesi beklenmektedir.

Fedorov, çeviri kuramı çerçevesinde üç alandan söz eder. Bunlar; çeviri etkinliklerinin ve çeviriye yönelik yaklaşımların gelişim tarihçesi; somut metinlerden elde edilen çeviri verilerinin sınıflandırılmasını ve genellemesini üstlenen genel çeviri kuramı ve metnin türüne ve dil çiftine bağlı olarak çeviri sorunlarını ve çeviri stratejilerini ele alan özel çeviri kuramıdır (Fedorov, 2002, s. 24). 
Fedorov'un farklı dil çiftlerine yönelik ve çeşitli metin türlerinin özelliklerini dikkate alacak çeviri kuramlarının geliştirilmesini savunduğu anlaşılmaktadır.

Fedorov'un çalışmasında çeviri sürecinde ortaya çıkan sorunların sözcüksel ve dilbilgisel olmak üzere iki grupta ele alındığı görülebilir. Sözcüksel düzeyde ortaya çıkan sorunlar arasında: 1) Hedef dilde karşılı̆̆ın olmaması 2) Hedef dildeki birim kaynak dildeki sözcüğün içeriğinin bir kısmını karşılar 3) Kaynak dildeki sözcüğ̈̈n farklı anlamlarının hedef dildeki farklı sözcüklerle karşılık bulmalarıdır (2002, s. 151).

Dilbilgisel sorunların da üç başlık altında toplandığı görülebilir. Fedorov, kaynak ve hedef dil arasındaki yapısal sorunlar arasında: 1) Kaynak dilde hedef dilde olmayan bir unsurun var olması 2) Hedef dilde olan unsurların kaynak dilde olmaması 3) Hedef ve kaynak dillerdeki unsurların biçimsel eşdeğerliği durumunda işlevsel uyuşmazlığın olmasıdır (2002, s. 198).

Fedorov’a göre sözcüksel ve dilbilgisel sorunların çözümünün yine bağlama göre yapılması gerekir. "Bir taraftan kaynak metnin içeriği ve üslubu, diğer taraftan ise, hedef dilin kurallar çeviri stratejilerini belirlemekte ve her seferinde farklilaştırmaktadı" (2002, s. 223). Böylece çeviri stratejilerinin çeviri sürecindeki iki dilin yapısına bağlı olduğu anlaşılmaktadır.

\section{Bütünlükçü Yaklaşım: V. G. Gak}

Fransızca-Rusça dil çifti üzerinde çalışan çeviribilimci Vladimir Grigoryeviç Gak, çalışmalarında ayrımsal dilbilim yaklaşımını uygulamış ve bu dil çifti için çeviri karşılıklarının belirlenmesinin yanı sıra Rus dilbilimsel çeviri ekolünün kuramı ve uygulamalarının temelini oluşturan çeviri dönüşümlerinin sınıflandırılmasını ileri sürmüş ve "eşdeğerlik seviyeleri” kavramını tanıtmıştır. Bununla birlikte Gak, bütünlükçü yaklaşımın sergilendiği ilk çeviri ders kitabının yazarı olarak tanınmaktadır. Y. Lvin ile birlikte çalıştıkları Kurs perevoda (Çeviri Dersleri) adlı ders kitabı ilk kez 1962 yılında yayımlanmıştır (Gak, 1962).

Gak'ın yaklaşımında çeviri "biçimin ve içeriğin bütünlüğünün yapılandırılması" olarak tanımlanmaktadır (Gak, 2000, s. 9). Ancak Gak, çeviri olgusunu salt ürün olarak değerlendirmemekte, karşılıkların bulunmasını amaçlayan süreç olarak ele almaktadır. Ayrıca çeviri sürecinde karşılıkların sınıflandırılması ve gerçeklik-dil ilişkileri üzerinde kurulan çeviri sürecinin modeli üzerinde odaklanılmaktadır.

Gak'a göre çeviri olarak tanımlanan yapılandırma, iki dil arasındaki karşlıkları bulma sürecidir. İki dil arasındaki sözcüksel ve dilbilgisel karşlıkların arkasında gerçekliği yansıtan olgular ve bu olgular arasındaki ilişkiler bulunmaktadır. Buna dayanarak çeviri sürecinde üç durumdan söz edilebilir: 1) Dilsel biçimlerin benzerliği 2) Dilsel biçimlerin farklı olmasına rağmen içeriklerin aynı olması 3) Yapılandırmanın aynı gerçekliğe (olaya) başvurularak gerçekleştirilmesidir. Bu durumdan yola çıkarak biçimsel, anlamsal ve durumsal olmak üzere üç çeviri modelinden ve üç çeviri eşdeğerlik seviyesinden söz edilebilir (Gak, 2000, s. 10).

Gak, çeviri karşıllı̆ının seçiminin çevirmen tarafından gerçekliğin ve dilsel olguların ilişkilendirilmesi ile gerçekleştiğini dile getirmektedir. Bu ilişkilendirme çeviri sürecinde dönüşüm biçiminde kendisini göstermektedir. Gak çeviri dönüşümlerinin belirlenmesinin ve sınıflandırılmasının çeviriye bilimsel dayanak sağlayacağını ve çeviri kuramının araştırma konusunu oluşturduğunu vurgulamaktadır (Komissarov, 2002, s. 60). 
Gak’a göre çeviri dönüşümleri nitelik ve nicelik kavramlarıyla tanımlanabilir. Nitelikli çeviri dönüşümleri söz yapısında değiştirmeyi öngörmekte, nicelikli dönüşümler ise, eklemeleri ya da çıkarmaları içermektedir. Gak’ın yaklaşımında nitelikli çeviri dönüşümleri üzerinde durulmaktadır. Nitelikli çeviri dönüşümleri beş türe ayrılmaktadır: 1) Dilbilgisel kategorinin değiştirilmesi (zaman, kip vs.). Rusça-Türkçe dil çifti için bu dönüşüm şu örneklerde görülebilir: 'в интересаx России' $\rightarrow$ 'Rusya'nın çıarına/menfaatine/leyhine', 'bir başka ifade ile' $\rightarrow$ 'другими словами' söz öbeklerinden Rusçada bazı anlamsal unsurların çoğul kategorisi ile kodlandığı, Türkçede ise aynı unsurların tekil kategorisi ile dile getirildiği anlaşılmaktadır. 2) Dilbilgisel kategorinin sınıfının değiştirilmesi. Rusça Türkçe dil çiftine yönelik şu örnekler verilebilir: 'bale okulu' $\rightarrow$ 'балетная школа', 'Orta Doğu sorunu''ближневосточная проблема', 'üç günlük ziyaret' $\rightarrow$ 'mpехдневный визит', 'çalsşта ziyareti' $\rightarrow$ 'рабочий визит', 'sütlü kahve' $\rightarrow$ 'кофе с молоком'. Görüldüğü gibi Rusça - Türkçe dil çiftinde dilbilgisel kategorinin sınıf değiştirmesi sıkça rastlanan bir durumdur. Bu grupta da farklı niteleme öbeklerinin yer aldığı görülebilir. Türkçede biri niteleyen, diğeri nitelenen olmak üzere iki nesne

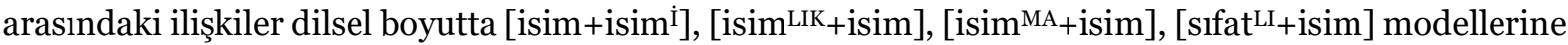
göre düzenlenebilirken, Rusçada iki nesne arasındaki ilişkiler [sıfat+isim] ya da [isim+edat+isim ${ }^{\mathrm{AD}}$ DURUMU] modellerine göre yapılandırılmaktadır. 3) Cümle arası ya da cümle içinde anlamsal ilişkilerin değiştirilmesi. Bu grupta analitik ve sentetik biçimlerin dönüşümlerinden kaynaklanan değiştirmeler yer almaktadır. Rusça-Türkçe dil çiftinde bu değiştirmeler sıkça rastlanan bir durumdur. Rusçadan Türkçeye çevirideki 'Девочки заговорились и не заметили, как прошло время' $\rightarrow$ 'Kızlar sohbete dalı zamanın nasıl geçtiğini fark etmediler', 'Она выговорилась, и ей стало легче' $\rightarrow$ ' İ̧ini döktükten sonra rahatladi', 'Ученый отказался выступать на мероприятии, отговорившись занятостью' $\rightarrow$ 'Bilim adamı meşgul olduğuпu bahane ederek etkinliğe katılmayı reddetti' gibi yapılandırmalardan anlaşıldığı gibi Rusçadaki ön ekli fiiller anlamın bir fiilde aktarılmasını sağlar ve bu şekilde sentetik biçimi ön plana çıkarmaktadır. Örneklerden Türkçedeki çeviri karşlıklarının birkaç sözcüksel unsurdan oluştuğu ve analitik biçimi yapılandırdığı anlaşılmaktadır. 4) Cümlede eylemcinesne arasındaki ilişkilerin değiştirilmesi. Bu çeviri dönüşümü Rusça-Türkçe dil çiftinde şu örneklerde görülebilir: 'Лодку все время отбрасывало волной от берега' $\rightarrow$ 'Dalgalar kayığ sahile yakınlaştırmıyordu', 'Ветром снесло крышу' $\rightarrow$ 'Rüzgar çatıyı uçurdu', 'Мне можно открыть подарок?' $\rightarrow$ 'Hediyeyi açabilir miyim?' örneklerinden anlaşıldı̆̆ gibi bu çeviri dönüşümü RusçaTürkçe dil çiftinde sıkça ortaya çıkabilmektedir. Bu çeviri dönüşümünü tetikleyen başlıca etken iki dilin farklı dünya görüşüdür. Rusçadaki eylemci bazı yapılarda pasif bir eylemci olarak karşımıza çıkmaktadır ('волной’ - 'dalga' sözcüğü araç durumunda (İnstrumental); 'ветром' - 'rüzgar' sözcüğü araç durumunda (İnstrumental); 'мне' - 'ben’ şahıs zamiri yönelme durumunda (Dativ). Türkçedeki eylemci ise yapısal boyutta daha aktif görünmektedir ('dalgalar yakınlaştırmıyor', 'rüzgar uçurdu', '(ben) açabilir miyim'). 5) Sözcüğün anlamsal alanının değiştirilmesi. Bu dönüşüm bir dildeki kavramlar arasında var olan beş tip mantıksal ilişkiye dayanmaktadır. Kavramlar arasındaki ilişkiler mantıktaki özdeşlik, çelişmezlik, bağlılık, türdeşlik, örtüşme (ya da eksik girişimlilik) gibi kategoriler açısından ele alınmaktadır. Bir örnek olarak bağlılık kategorisi gösterilebilir. Rusçada hayvan-yavru ismi paradigması çoğu zaman aynı kök üzerinde kurulmakta ve her hayvanın kendi yavrusunu isimlendiren sözcük tercih edilmektedir. Ayrıca, 'кошка - котенок' (kedi - kedi yavrusu), 'собака - щенок' (köрек - kӧрек yavrusu), 'волк - волчонок' (kurt - kurt yavrusu), 'белка - бельчонок' (sincap - sincap yavrusu), vs. gibi isimlerin genel adı 'детеныш’ (yavru) olmasına rağmen ayrı isimler tercih edilmektedir. Türkçede bu durumlarda 'yavru' kavramı kullanılabilmektedir. Böylece Türkçedeki 'Kedinin beş yavrusu oldu' cümlenin Rusça karşılı̆̆ı ‘Кошка родила пять котят’ biçiminde olur.

Gak'ın kuramında çeviri sorunları sözcüksel, dilbilgisel ve biçemsel olarak gruplandırılmaktadır. Sözcük seviyesinde diller arası karşılıkların belirlenmesi üzerinde durulmaktadır. Gak, sözcüksel karşılıkları 
gruplara ayırmaktadır. Bunlar 1) sabit eşdeğeri olan sözcükler 2) kaynak dildeki sözcüğün hedef dilde birçok karşıllı̆̆ olan sözcükler 3) eşdeğeri olmayan sözcüklerdir.

Gak’ın çeviri dönüşümlerinin betimlenmesi ve sınıflandırma denemesi, çeviri dönüşümlerinin çeviride eşdeğerliğin var olmasını desteklediği fikri, diğer araştırmacılar tarafından dikkate alınmış ve çalışmalarında geliştirilmiştir. Bunun dışında Gak’ın Fransızca-Rusça dil çifti için betimlediği çeviri dönüşümleri kavramı diğer dil çiftlerine uygulanmış ve çeviri bölümlerinde ders kitaplarının temelini oluşturmuştur.

\section{5. İşlevsel Yaklaşım: A. D. Şveytser}

Dilbilimci ve çeviribilimci Aleksandr Davıdoviç Şveytser’in çağdaş dilbilimin yaklaşımlarını birleştiren çeviri kuramı 1973 yılında yayımlanan Perevod i lingvistika (Çeviri ve Dilbilim) ve 1988 yılında basılan Teoriya perevoda: status, problemı, aspektı (Çeviri Kuramı: Kavramlar ve Sorunlar) adlı kitaplarda yansıtılmıştır. Şveytser'in yaklaşımı iletişimsel olarak nitelenebilir. Şveytser'in yaklaşımında çevirinin konuşma eylemi olarak ele alındığı ve çeviride yeterliliğinin ilk defa metin kavramı bazında değerlendirilmeye çalışıldığı görülebilir.

Şveytser'e göre çeviri sürecinde dilsel olgularla birlikte dil dışı etkenlerin dikkate alınması gerekmektedir. Bu yaklaşım Şveytser’in çeviri tanımını da şekillendirmiştir. Ona göre çeviri,

"kaynak dildeki metnin çeviri amaçh çözümlemesi bazında başka dilsel ve kültürel ortamda bu metnin yerine geçen hedef dildeki ikincil metnin oluşturulmasını içeren tek yönlü ve iki aşamah diller ve kültürler arası iletişim sürecidir. Bu süreç, iki dil, kültür ve iletişim ortamından kaynaklanan farklhlıklarm etkisiyle değişkenlik gösteren kaynak dildeki metnin iletişimsel etkisinin aktarılmasını öngörmektedir." (Şveytser, 1988, s. 75).

Görüldüğü gibi çeviri sürecinde çevirmenin kaynak ile hedef metin ve kültür arasında dengeyi koruması beklenmekte ve kaynak metnin iletişimsel etkisinin korunması öngörülmektedir.

Şveytser'e göre çeviri sürecinde değişmez olan ve korunması gereken unsur kaynak metnin işlevsel içeriğidir (1973, s. 70). İşlevsel içerik, çeviri amacının ve metnin özelliklerine dayanan, kaynak metnin içerdiği anlamsal ve edimsel ilişkiler bütünlüğü olarak nitelenebilir. Şveytser’in, bu tanımdan yola çıkarak çeviri sürecinde ortaya çıkan sorunların anlamsal, biçemsel ve edimsel olarak üçe ayırdığı görülebilir. Şveytser her sorun türü üzerinde durmakta ve çeviri stratejilerini belirlemeye çalışmaktadır.

Şveytser, anlamsal sorunları sözcüğün düz anlamı ile ilişkilendirmektedir. Çeviri sürecindeki anlamsal sorunların algılanmasının içerik - anlam ilişkilerinin çözümlenmesine bağlı olduğu anlaşılmaktadır. Şveytser içerik ve anlam kavramını ayırmakta ve anlamı söz sürecinde kendini gösteren içerik olarak tanımlamaktadır (1988, s. 114). Söz ya da bağlam farklı dillerdeki sözcüklerin içerikleri arasındaki farkları nötrleştirmekte ya da aynı anlamın aktarılması için farklı içeriklerin kullanımını mümkün kılmaktadır. Aynı anlamı sağlayan farklı içeriklerin aktarımı çeviri dönüşümleri sayesinde olabilmektedir.

Şveytser’in yaklaşımında çeviri dönüşümleri anlambirimciklerinin sayısının değişmediği dönüşümler ve anlambirimciklerinin farklılaştığ çeviri dönüşümleri olarak ayrılmaktadır. Anlambirimciklerinin farklılaşmadığı çeviri dönüşümlerinin temelinde anlambilimsel çözümlemenin bulunduğu görülebilir. Kaynak dildeki sözcüğün anlambirimciklerinin belirlenmesi ve hedef dildeki bu anlambirimciklerinin bir araya geldiği uygun bir dilsel biçimin bulunması beklenmektedir. Örneğin Rusçadaki ‘заговоритъ’ 
fiili 'konuşmak' ('говор-' kökü) ve 'başlamak' ('за-' ön eki) anlambirimciklerine ayrılabilir. Türkçede bu iki anlambirimciğinin dile getirildiği biçim 'konuşmaya başlamak' şeklindedir. Burada Rusçadaki bir fiile dilbilgisel dönüşümün uygulandığı ve bu uygulamanın sonucunda Türkçede iki fiilin ortaya çıtığı görülebilir. Bu yaklaşımdan çeviri dönüşümlerinin dil çiftine bağlı olduğu, ayrıca dilin sözcük yapım modelleri, sözcük yapısı, sözcüksel ve sözdizimsel uyum (eşdizim) gibi kriterlere göre uygulanabildiği anlaşılmaktadır.

Anlambirimciklerinin farklılaştığı çeviri dönüşümlerinin etkenleri arasında; sözcüğün iç biçiminin farklı olması, ikincil adlandırmalar, gerçekliğin dile getirilmesi biçiminde tanımlanabilen dilsel dünya görüşü, sözcüksel boşluklar bulunmaktadır. Sözcüğün iç biçiminin farklılı̆ğ şu örnekle gösterilebilir: 'çivi çakmak' - 'yoğurt çırpmak' - 'bardak kırmak' - 'cevizi (ă̆açtan) düşürmek' gibi olaylar Türkçede farklı iç biçimi olan fiil kökleri ile dile getirilmektedir. Başka bir deyişle ilgili mantık olayları Türkçede farklı imgelerle ilişkilendirilmektedir. Rusçada ise bu olaylar "bir noktadan gelen ivme, çaba, güç uygulaması" imgesi üzerinde toplanmakta (fiil kökü) ve hareketin yönünü kodlayan dilsel birimlerle (ön ek) desteklenmektedir (Kozan, 2019, s. 66). Aуrıca 'вбить гвоздь' $\rightarrow$ В [içeriye doğru bir hareket] + БИТь [bir noktadan gelen çaba, ivme, güç uygulaması] $\rightarrow$ çivi çakmak; 'взбить ŭoгypm' $\rightarrow$ B3 [yukarıya doğru bir hareket] + БИТЬ $\rightarrow$ yoğurt çırpmak; 'разбить стакан' $\rightarrow$ PA3 [bir noktadan farklı yönlere dağılma; olgunun iç yapısının dağılması] + БИТЬ $\rightarrow$ bardak kırmak; 'cбить opex' $\rightarrow$ C [bir noktadan aşağıya doğru hareket] + БИТЬ $\rightarrow$ cevizi düşürmek. İkincil adlandırmalardaki farklılık şu örneklerde görülebilir: 'kitap kapağ - обложка книгu', 'tencere kapağı - крышка кастрюли'; 'dolap kараğ дверца шкафа'; 'şişe kapağı- пробка'. Türkçedeki adlandırmalarda 'kapatmak' eylemi odaklı 'kapak' imgesi farklı nesnelerle ilişkilendirilebilmektedir (Kozan, 2018, s.157). Rusçaya bakıldığında yine farklı dilsel birimlerin ortaya çıktığı anlaşılmaktadır. Bu da adlandırmaların farklı mantığa göre şekillendiği anlamına gelmektedir. İki dilin dünya görüşü arasındaki fark dünya görüşündeki farklılığı ' $М н е$ холодно' - 'Üşüdüm' cümlelerinde görülebilir. Rusçada fizyolojik durumu dile getiren yapı eylemci yönelme durumu (Dativ) ile dile getirilir ve dışarıdan gelen gücün etkisiyle bir eylem yapmamakta, bir durumda kendisini bulmaktadır (nötr biçimle (burada zarf) dile getirilir). Türkçede ise, fizyolojik durumu aktif yalın haldeki eylemci ve fiilin çekimi ile dile getirilmektedir (Kozan, 2016). Türkçede sözcüksel boşluğun örneği Rusçadaki karpuz, domates, orman ve bahçe meyvelerini birleştiren 'ягодъ' sözcügüdür. Rusça açısından boşluk Türkçedeki 'kuru yemiş’ sözcüğü oluşturmaktadır (Rusçaya açıklamalı bir şekilde aktarılabilir: 'солёные и засахарённые орешки').

Şveytser'in yaklaşımında çevirinin değerlendirilmesine yönelik işlevsel eşdeğerlik kavramı kullanılmaktadır. İ̧̧levsel eşdeğerlik, çeviri metninin kaynak metindeki gerek anlamsal gerekse biçemsel özelliklerini içermesi olarak tanımlanmaktadır (Şveytser, 1973, s. 264). Eşdeğerlik sözdizimsel, anlamsal ve edimsel seviyelerde ele alınmaktadır. Şveytser'e göre edimsel seviyede eşdeğerlik çevirmenin anlamsal eşdeğerlikten vazgeçmesini gerektirebilir (1973, s. 268).

\section{Göstergebilimsel Yaklaşım: L. S. Barhudarov}

Leonid Stepanoviç Barhudarov'un 1975 yılında çıkan Yazık i perevod (Dil ve Çeviri) adlı çalışmasındaki yaklaşımın göstergebilim ve anlambilimin sunduğu modele göre geliştirildiği söylenebilir.

Barhudarov, göstergebilim ve anlambilim çerçevesinde geliştirilen dilsel içerik kuramını ele alır ve dilsel içeriğin zihinsel oluşumla ilişkilendirilmesinin hatalı olduğunu öne sürer (1975, s. 50). Bahudarov, dilsel gösterge - dilsel içerik ilişkilerini ayrıntılı bir şekilde ele alır ve kendi yorumunu dile getirir. Araştırmacı, dilsel içeriğin zihinsel bir oluşum olmadığını vurgulayıp, "dilsel göstergelerin içerikleri insanın zihninde 
değil, göstergelerde var olmakta, böylece, insanın beyninde değil, sözde var olmaktadır” şeklindeki yaklaşımı sergiler (1975, s. 55). Ancak içerik, sözde sürekli var olan bir oluşum değil, ilişkilerdir. İnsanın zihninde oluşan ise, içerik değil, dilsel içerik ile ilgili bilgilerin toplamıdır (Barhudarov, 1975, s. 61).

Barhudarov göstergebilimsel yaklaşıma dayanarak dilsel göstergenin içeriklerini üç türe ayırmaktadır. Ayrıca gönderge ile gösterge arasındaki ilişkileri niteleyen göndergesel içerikler (dilbilimdeki düz anlam); insan ile gösterge arasındaki ilişkileri tanımlayan edimsel içerikler (yan anlam); gösterge ile diğer göstergeler arasındaki ilişkileri niteleyen dil içi içerikleri söz konusudur (Barhudarov, 1975, s. 68). Böylece dilsel göstergenin anlamsal içeriği göndergesel, edimsel ve dil içi içeriği olmak üzere üç unsurdan oluşmaktadır.

Barhudarov dilsel içeriklerin türlerinin hepsinin çeviri sürecinde korunup korunmadığg sorusu üzerinde durmaktadır. Barhudarov'a göre bu sorunun tek bir cevabı olmasa da, çeviri sürecinde en çok göndergesel içeriklerin korunması gerekmektedir. Ayrıca, "çeviri sürecinde 'yüksek çevrilebilirliği' olan göndergesel içeriklerdir" (Barhudarov, 1975, s. 71). Buna göre edimsel içeriklerin çevrilebilirlik derecesi daha da düşük, dil içi içeriklerinin aktarım derecesi ise en düşük olarak nitelenebilir. Barhudarov, dilsel içeriklerin çeviri açısından önceliğinden söz ederken göndergesel içeriklerin önemini dile getirse de, öncelik kavramının metnin türüne göre değişebileceğini de vurgulamaktadır (Barhudarov, 1975, s. 72). Böylece, dilsel içeriklerin genel aktarım sırasının verilmesi mümkün değildir.

Barhudarov'un yaklaşımında bağlam kavramının çok önemli bir rol oynadığı görülebilir. Bağlam, dil biriminin kullanıldığı dilsel ortam olarak tanımlanmaktadır (Barhudarov, 1975, s. 169). Bağlam cümle olarak nitelenebilen dar bağlam ve metin olarak düşünülen geniş bağlam olarak değerlendirilmektedir. Dar bağlam sözcüksel ve sözdizimsel olarak ayrılmaktadır. Sözcüksel bağlam, sözcüğün ortaya çıkabildiği sözcüklerin, söz öbeklerinin, eşdizimlilerin ve deyimlerin toplamıdır. Sözdizimsel bağlam ise, sözcüğün, söz öbeğinin ya da yan tümcenin kullanıldığı sözdizimsel yapıdır. Barhudarov, çeviri sürecinde sözcüklerin çok anlamlılı̆̆ı sorununun bağlam içinde çözülebildiğini vurgular.

Barhudarov, bağlamın yanı sıra dil dışı bağlamından de söz eder. Dil dışı bağlamı; konuşma eyleminin gerçekleştiği zaman ve mekân, iletinin konusu ve konuşma eyleminin katılımcılarını içeren koşulların toplamı olarak tanımlanmaktadır (Barhudarov, 1975, s. 172). Dil dışı bağlamının çeviri sürecinde bazı durumlarda dil içi bağlamından daha önemli olabildiğine dikkat çekilmektedir. Rusça - Türkçe dil çifti için şu örnek verilebilir: Türkçe metinde 'Yunanistan'da hayırcılar meydanları doldurdu'2 cümlesindeki 'hayırcı' diye bir sözcükle karşılaşıldığında, sözcüğün iç biçiminden yola çıkarak, 'hayırcı' - 1) 'bir şeye 'hayır' diyen, bir şeyi inkar eden biri' 2) 'karşllık beklemeden yardım yapan biri' şeklinde yorumlanabilir. Bu durumda dil içi bağlamının cümledeki olayın anlaşılması için yeterli olmadığı anlaşılmaktadır. Dil dışı bağlamından 'hayırcı'nın, Yunanistan'da Haziran 2015 yılında düzenlenmiş referandumda uluslararası kreditörlerin taleplerine karşı çıkan ve oylamada 'hayır' oyunu verenler olduğu anlaşılmaktadır. Böylece 'hayırcı $\rightarrow$ противник требований еврокредиторов' biçiminde bağlama göre türetilmiş bir karşılık karşımıza çıkmaktadır. Bu durumda Rusça çeviri seçeneklerinden biri, 'На площадях в Греции собрались противники требований еврокредиторов' biçiminde yapılandırılmış cümle olabilir.

Barhudarov dar, geniş ve dil dışı bağlamının dikkate alınmadığı sürece çevirinin mümkün olmayacağını dile getirir ve çeviri kuramının ne olması gerektiğine dair önemli bir fikri ileri sürer. Ayrıca "çeviri kuramını dilbilimsel temelinin, metindilbilim ve dil dışı etkenleriyle etkileşim içinde olan dil

2 http://www.radikal.com.tr/dunya/yunanistanda-hayircilar-meydani-doldurdu-1390870/ (Erişim: 04.05.2019) 
dizgesinin işleyişinin dikkate alındiğı bilimsel betimleme olması gerektiği" vurgulanmaktadır (Barhudarov, 1975, s. 173).

\section{7. Çeviride Bilgi Aktarımı: R. K. Minyar - Beloruçev}

Ryurik Konstantinoviç Minyar-Beloruçev'in çeviriye yönelik geliştirdiği yaklaşımı 1980 yllında yayımlanan Obşçaya teoriya perevoda $i$ ustnıy perevod (Genel Çeviri Kuramı ve Sözlü Çeviri) adlı çalışmada yansıtılmıştır. Minyar-Beloruçev'in yaklaşımında daha sonra bilişsel bilimlerde ele alınan bilgi kavramıyla iletişim kuramının uygulandığı görülebilir. Minyar-Beloruçev çalışmasında "bilgi birikimi" kavramını tanıtıp, çeviri sürecinde bilginin aktarımına dayalı bir yaklaşım geliştirmeye çalışmaktadır. Bu yaklaşımda başta çeviri birimi, çeviri karşılıkları, bilgi yoğunluğu, bilgi türleri, çeviri hataları olmak üzere bazı kavramlar üzerinde durulduğu görülebilir.

Minyar-Beloruçev'in yaklaşımında iletişim türü olan çeviri, iletişimin gerçekleştiği ortam, koşullar ve katılımcılar açısından ele alınmaktadır. Minyar-Beloruçev, çeviri iletişim türü ise incelenmesinin konuşma eyleminden başlanması gerektiğini dile getirir (1996, s. 16). Konuşma eyleminin yapısına kaynak, alıcı, gönderici, ileti ve iletişim ortamı gibi unsurlar dahil edilmektedir. Çeviri sürecinde tüm unsurların önemli olduğunu vurgulayan Minyar-Beloruçev, dilsel olgu olan iletiyi ayrıntılı bir şekilde ele almaktadır.

İleti, unsurlardan ve unsurlar arasındaki ilişkilerden oluşan bir dizge olarak tanımlanır. MinyarBeloruçev'e göre çeviri sürecinde iletinin içeriğinin yanı sıra iletinin yapısı da önemli bir rol oynamaktadır (1996, s. 23). Diğer bir deyişle iletinin anlamını anlayabilmek ve başka bir dile aktarmak için sadece anlamsal içeriği değil iletinin gerçekleştiği ortam ile ilgili bilgiler de gerekmektedir. Bu ileti kavramının, çeviri tanımının temelini oluşturduğu görülebilir. Ayrıca Minyar-Beloruçev çeviriyi "kaynak metnin kodu ile hedef ahcını kodunun örtüşmediği durumlarda iletinin aktarmmın amaçlayan söz faaliyetinin karma bir türü" şeklinde tanımlamaktadır (1996, s. 36).

Minyar-Beloruçev çeviri sürecine yönelik iletinin "değişmez unsur"u kavramını ileri sürer:

"Çeviri açısından ele alnnan iletinin değişmezi, iletilmesi amaçlanan bilgi ya da iletidir. Bu anlamsal bilgi, iletinin gerçekleștiği ortam ya da durum ile ilgili bilgi, iletinin yapıss ile ilgili bilgi ya da anlamsal ve yapısal bilgilerin toplamı biçiminde olabilir. Böylece aktarılması amaç̧lanan tüm bilgi türleri iletiyi oluşturmaktadır" (Minyar-Beloruçev, 1996, s. 36).

Çeviri sürecinde iletiyi oluşturan bilgi türlerinin belirlenmesi beklenmektedir.

Minyar-Beloruçev'in yaklaşımında iletinin, sadece bilgi türleri açısından değil, alıcı tarafından ele alındığı görülebilir. Araştırmacı "bilgi birikimi" kavramını ileri sürmektedir. Bilgi birikimi konuşmacının gönderge ya da dilsel gösterge ile ilişkilendirdiği bilgilerin toplamı olarak tanımlanmaktadır (Minyar-Beloruçev, 1996, s. 46). Minyar-Beloruçev konuşmacıdaki bilgi birikiminin derecelendirme denemesini yapmaktadır. Ayrıca bilgi birikiminin beş dereceye göre yapılandırılabildiği varsayılmaktadır. Bunlar, 1) Dilsel birimin gerçeklikteki bir nesne ya da olgu ile ilişkilendirilmesini sağlayan temel bilgiler ('Kilimanjaro' - coğrafya terimi) 2) Dilsel birimin belli bir alanla ilişkilendirilmesini sağlayan bilgiler ('Kilimanjaro' - dağ) 3) Gerçeklikteki olgunun dilsel boyutta adlandırılmasını sağlayan bilgiler ('Kilimanjaro' - Afrika'nın en yüksek noktası) 4) Olgu ile ayrıntıları sınıflandıran bilgiler (yükseklik, konumu, özellikleri vs.) 5) Olgunun içeriği, diğer olgularla ilişkileri, ayırt edici özellikleri ile ilgili bilgilerdir. Minyar-Beloruçev'e göre bilgi birikimindeki birinci ve ikinci derece dilsel birimin temel kullanımı sağlamaktayken, üçüncü derecedeki bilgi birikimi dilsel 
göstergenin çeviri sürecinde kullanımına olanak vermektedir. Buradan yola çıkarak diğer önemli bir nokta, metnin bilgi yapısının alıcıya göre değişebildiği varsayımıdır (Minyar-Beloruçev, 1996, s. 52).

Minyar-Beloruçev iletiye yönelik "bilgi yoğunluğu" kavramını da kullanmaktadır. İleti yazllı ya da sözlü metin biçiminde alıcıya ulaşmaktadır. Metin ise "ortak amaçla birleştirilen seslerin ya da harflerin sıralanışı değil, farkh değerdeki bilgiyi taşıyan dilsel birimlerin dizgesi"dir (Minyar-Beloruçev, 1996, s. 71). Metni oluşturan dilsel birimler farklı bilgi türleri içerebilmektedir. Ayrıca Minyar-Beloruçev 1) eşsiz bilgi 2) ek bilgi 3) somutlaştıran bilgi 4) tekrarlanan bilgi 5) sıfır bilgi olmak üzere beş bilgi türünden söz eder. Eşsiz bilgi türü dil içi ya da dil dışı bağlamının belirlemediği bilgilerdir. MinyarBeloruçev’in yaklaşımına göre, bu bilgi türünü taşıyan dilsel birimlerin çeviri sürecinde yüzde yüz oranında aktarılması gerekmektedir. Bu dilsel birimler değişmez olarak nitelenebilir (MinyarBeloruçev, 1996, s. 69). Ek bilgi türü, metinde açık bir şekilde yansıtılmayan ancak bağlam, iletinin mantığı, alıcının bilgi birikimine bağlı olarak çıkarılabilen bilgi türüdür. Somutlaştıran bilgi, metnin diğer dilsel birimlerindeki bilgilerin parçasını oluşturmakta ve bu bilgileri somutlaştırmaktadır (Minyar-Beloruçev, 1996, s. 70). Tekrarlanan bilgi türü metindeki tekrarlamalar anlamına gelmekte ve sözlü metinlerde yaygın olarak kullanılmaktadır. Sıfır bilgi türü ise farkında olmadan yapılan dil bozuklukları, düzeltmeler gibi anlamsal bilgi taşımayan dilsel birimlerdir. Minyar-Beloruçev bazı sıfır bilgi taşıyan sözcüklerin iletişimde yapıcı bir rol oynayabildiğini vurgular. Ayrıca bu unsurların konuşmacıya iletişim sırasında düşünmek için zaman kazandırmaktadır (Minyar-Beloruçev, 1996, s. 71).

Minyar-Beloruçev’in bilgi türü yaklaşımının Rusça-Türkçe dil çiftine yönelik uygulanması aşağıdaki örneklerde görülebilir. Rusçadaki "По итогам сегодняшних переговоров Президента России Владимира Путина и его турецкого коллеги Реджепа Тайипа Эрдогана между Россией и Турцией было подписано межправительственное соглашение по реализации проекта о строительстве газопровода "Турецкий поток"з “"Rusya Başkanı Vladimir Putin ile onun Türk mevkidaşı Recep Tayip Erdoğan arasında bugün gerçekleşen görüşmelerin sonunda Rusya ve Türkiye arasında 'Türk akımı' doğalgaz boru hattı projesi için hükümetlerarası anlaşma imzalandı”) cümlesinde eşsiz bilgi 'Rusya', 'Türkiye', 'anlaşma', 'Türk akımı', 'imzalandı' birimlerinde kodlanmaktadır. Ek bilgi türü 'bugün', 'görüşmelerin sonunda', 'doğalgaz', 'Vladimir Putin', 'Recep Tayip Erdoğan', 'hükümetlerarası' birimlerinde bulunabilir. Somutlaştıran bilgi Rusçadaki, 'строительство' birimlerinde bulunabilir. Türkçedeki yapılandırmada bu birimdeki somutlaştıran bilgi kastedilmektedir ve dilsel boyuta yansitılmayabilir. Tekrarlanan bilgi 'Rusya Başkanı', 'Türk mevkidaşı', 'gerçekleşen', ‘boru hattı', 'proje', Rusçadaki ‘строительство', 'реализация’ (Türkçe yapılandırmasında 'bilgi fazlalığı' olarak değerlendirilebilir, 'doğalgaz boru hattı projesi' öbeğinde gizli olarak kastedilmektedir). Farklı söylemlerde sıkça ortaya çıkan sıfır bilgi örneği şu şekilde verilebilir: 'Başka bir deyişle', 'yani', 'bilindiği gibi' birimleridir.

Minyar-Beloruçev çeviri sürecinde çeviri birimi sorununu ayrıntılı bir şekilde ele almaktadır. MinyarBeloruçev'e göre çeviri birimi "çeviri sürecinde ayrı çeviri çözümünü gerektiren sözün herhangi birimi"dir (1996, s. 79). Araştırmacıya göre çeviri biriminin belirlenmesi çevirmenin mesleki deneyimi, bilgi birikimi gibi unsurlara bağlıdır. Çeviri birimi simültane, yazılı, ardıl gibi çeviri türlerinde farklı nitelikte olabilmekte ancak bağımsız olarak düşünülebilen çeviri birimleri de söz konusudur. MinyarBeloruçev bağımsız çeviri birimleri grubuna sözlü veya yazılı metinlerde tekrarlanan kalıpları ('Переговоры прошли в конструктивном ключе' - 'Görüşmeler yapıcı bir atmosferde geçti'), duruma bağlı kalıpları ('Примите мои соболезнования’ - 'Başınız sağ olsun'), terimleri ('Военный советник’ -

3 https://ria.ru/20161010/1478918382.html (Erişim: 04.05.2019). 
'Askeri müsteşar'), imge içeren deyimleri ('Поспешишь-людей насмешишь' - 'Acele işe şeytan karışır') dahil etmektedir (1996, s. 87).

\section{Eşdeğerlik Kuramı: V. N. Komissarov}

Vilen Naumoviç Komissarov'un geliştirdiği kuramsal yaklaşımlar 1980 yllında yayımlanan Lingvistika perevoda (Çevirinin Dilbilimi) ve 1990 yılında çıkan Teoriya perevoda (Çeviri Kuramı) adlı çalışmalarda yansıtılmıştır. Komissarov'un çeviriye yönelik yaklaşımının temelinde eşdeğerlik kavramı bulunmaktadır. Eşdeğerlik ayrıntılı bir şekilde ele alınmakta ve eşdeğerlik sınıflandırma denemesi yapilmaktadır.

Komissarov'un yaklaşımında çeviri kuramının önemi vurgulanmaktadır. Araştırmacı çeviri kuramının geliştirilme sürecinde çevrilmezlik kavramının geçerliliğini yitirdiğini dile getirmektedir. Komissarov'a göre kaynak metnin içeriği hedef metnin içeriği ile aynı değildir. Belli tarihi ve kültürel şartların şekillendirdiği dil dışı bilgi birikimi olan dil taşıyıcılarından oluşan topluluğa hitap eden metnin dilsel özellikleri başka bir dilde tam olarak yapılandırılamaz. Ancak çeviri sürecinde bazı unsurların kaybı metnin çevrilmez olduğunu göstermez. Hedef metnin kaynak metin ile aynı olmaması, kaynak metnin işlevlerinin hedef metin ile gerçekleşmesini engellemez (Komissarov, 1990, s. 39). Görüldüğü gibi Komissarov'un yaklaşımında çeviri kavramı iletişim süreci ve metnin işlevi ile ilişkilendirilmektedir. Çeviri, "kaynak dildeki metnin işlevsel olarak eşdeğeri olan metin ile hedef dilde yapılandırıldığı dilsel aracılık türüdür" biçiminde tanımlanır (Komissarov, 1990, s. 45).

Komissarov, çeviri eşdeğerliğini beş seviyede ele alır. Eşdeğerliğin sınıflandırılmasının iletişim amacı, bakış açısı, dilsel betimleme biçimi, sözcüksel ve sözdizimsel yapı gibi kavramlara göre yapıldığı görülebilir.

Birinci seviye eşdeğerliği iletişim amacını oluşturan içeriğin bir kısmının korunmasını öngörmektedir. Örneğin Rusça - Türkçe dil çifti için ‘Выносить сор из избы’ (sözcüğü sözcüğüne: evdeki çöpü dışarıya götürmek) - 'Kirli çamaşırlarını ortaya dökmek' sözünden iki dildeki imgelerin, yapıların farklı olduğu, ama aynı amaç için kullanılabildiği anlaşılmaktadır. Komissarov, bu eşdeğerlik türü için şu özellikleri sıralamaktadır: 1) İki metin arasındaki sözcüksel içeriğin ve sözdizimsel yapıların uyuşmazlı̆̆ı) Kaynak metindeki sözcükler ile yapı arasında anlamsal ya da sözdizimsel değiştirmelerin yapılamaması 3) Kaynak ile hedef metinler arasında doğrudan mantık ilişkilerinin bulunmaması 4) Diğer eşdeğerlik seviyelerine göre içerik açısından en düşük eşdeğerlik derecesidir (1990, s. 53).

İkinci seviye eşdeğerliği iletişim amacının aktarımının yanı sıra aynı dil dışı olayını yansıtmaktadır. Burada Komissarov dil dışı olayının dile getirilişi ya da dilsel betimleme biçimi kavramları üzerinde durmaktadır. Dil dışı olayı, dile getirilen ve sözde gerçekleşen nesnelerin ve gerçeklikteki nesne arasındaki ilişkilerin bütünü olarak tanımlanmaktadır (Komissarov, 1990, s. 54). Her dilde bir dil dışı olayı farklı biçimlerle yansıtılabilir. Bu bağlamda çeviri sürecinde aynı dil dışı olayının yapılandırılması ve yapılandırma biçiminin ayrı bir şekilde ele alınması gerekmektedir. Komissarov, "bir nesnenin masada bulunması" dil dışı olayının betimlenmesinin temelinde "durum", "algılama", "eylem" gibi kavramların bulunabildiğini dile getirmektedir. Bu anlamda 'Kitap masada duruyor' ya da 'Kitap masadadır' (durum), 'Ben masada kitap görüyorum' (algllama), 'Kitap masaya bırakıldı' (eylem) cümleleri aynı dil dışı olayını yansıtmaktadır (1990, s. 56). Böylece ikinci seviye eşdeğerliği kaynak ve hedef metinlerde aynı dil dışı olayının bulunması ve farklı betimleme biçimlerinin olmasını öngörmektedir. Örneğin 'Он снял трубку' (ahizeyi kaldırdı) - 'Telefonu açtı' cümlelerinde dil dışı 
olayının aynı olduğu ama iki dilde farklı biçimlerle dile getirildiği görülebilmektedir. İkinci seviye eşdeğerliği türü için 1) iki metin arasındaki sözcüksel içeriğin ve sözdizimsel yapıların uyuşmazlığı 2) kaynak metindeki sözcükler ile yapı arasında anlamsal ya da sözdizimsel değiştirmelerin yapılamaması 3) iletişim amacının korunması 4) hedef metinde kaynak metindeki dil dışı olayının korunması gibi özellikler söz konusudur (Komissarov, 1990:58). Komissarov, ikinci seviye eşdeğerliğin çeviri sürecinde slkça başvurulan bir tür olduğunu dile getirmektedir. Bunun sebebi her dilde tarihsel ve kültürel etkenlerin belirlediği kendine özgü bakış açllarının var olmasıdır. Komissarov, İngilizcedeki 'We locked the door to keep thieves out' cümle örneğini sunarak bu dil dışı olayının Rusçada aynı biçimde dile getirilemeyeceğini vurgulamaktadır. Aynı durum Türkçe için de geçerlidir. Ayrıca 'We locked the door to keep thieves out' $\rightarrow$ 'Мы заперли дверь, чтобы не вошли воры' $\rightarrow$ 'Hırsizlar girmesin diye kapıy kilitledik' cümlelerinden ilgili dil dışı durumunun Rusçada ve Türkçede aynı bakış açısıyla dile getirildiği anlaşlmaktadır.

Üçüncü seviye eşdeğerliğin özellikleri arasında; 1) iki metin arasındaki sözcüksel içeriğin ve sözdizimsel yapıların uyuşmazlığı 2) kaynak metindeki sözcükler ile yapı arasında anlamsal ya da sözdizimsel değiştirmelerin yapılamaması 3) iletişim amacının korunması 4) dil dışı olayının dile getirildiği biçimin kısmen korunması bulunmaktadır (Komissarov, 1990, s. 61). Üçüncü seviye eşdeğerliğin görülebildiği Rusça - Türkçe örneklerden biri, ‘От мытья полов у меня настроение портится’ $\rightarrow$ 'Yerleri silmek canımı sıkar' çeviri seçeneğidir. Örnekten anlaşıldığı gibi iki cümledeki anlambirimcikleri aynı dil dışı olayını yansıtırken cümle içinde farklı bir şekilde gruplandırılmaktadır. Rusçada anlambirimciklerin gruplanması [D (от мытья полов) dolayısıyla B’nin (у меня) yanındaki A (настроение) C özelliğini (портится) kazanmakta] biçimindedir. Türkçede ise bu gruplandırma [süreç niteliğindeki D (yerleri silmek) B'e ait A'ı (canımı) C (sıkıyor) yaptırarak, etkilemektedir] biçimindedir.

Dördüncü seviye eşdeğerliğin özellikleri arasında; 1) iletişim amacının korunması, 2) dil dışı olayının sözcükselleştirildiği biçimin korunması, 3) kaynak metindeki sözdizimsel yapıların tekrarlanması ya da sözdizimsel dönüşümlerin kullanılabilmesinin yanı sıra kaynak ve hedef metindeki sözcük birimlerinin kısmi örtüşmesi bulunmaktadır (Komissarov, 1990, s. 70). Rusça - Türkçe dil çifti için örneklerden biri 'Вчера футболисты в Бразилии провели сидячую забастовку' $\rightarrow$ 'Dün Brezilya'daki futbolcular oturma eylemi gerçekleştirdiler’ çeviri seçeneğidir.

Beşinci seviye eşdeğerliği durumunda kaynak ve hedef metinler arasında mümkün olan en yüksek yakınlık derecesi elde edilmektedir. Özellikleri arasında sözdizimsel yapıların yakınlığı, sözcük birimlerin yakınlığı, kaynak metnin içeriğinin tüm boyutlarının korunması bulunmaktadır (Komissarov, 1990, s. 78). Bu eşdeğerlik türü üzerinde duran Komissarov sözü oluşturan sözcüklerin anlamsal yapısını ele almaktadır. Ayrıca, Komissarov’un yaklaşımında sözcüğün anlam yapısında düz anlam, yan anlam ve dil içi anlamı olmak üzere üç anlamsal boyut söz konusudur. Çeviri sürecinde anlamı oluşturan bu üç boyutun tamamının aktarılması son derece zor, hatta bazen olanaksızdır. Bu durumda eşdeğerlik, bu konuşma eyleminin koşullarında gerekli olan anlam unsurlarının aktarılması ile sağlanmaktadır. Her anlamsal unsurun aktarımı çevirmeni bir takım sorunlarla karşı karşıya getirmektedir.

Komissarov'un yaklaşımında çeviri stratejileri üzerinde durulmamaktadır. Araştırmacıya göre çeviri stratejileri kaynak ve hedef diller arası ilişkilere ve çeviri amacına bağlı olduğundan çevirmenin genel stratejisini belirleyen ilkelerden söz etmek daha doğrudur. Ayrıca Komissarov’a göre çevirmenin stratejisini belirleyen ilkeler arasında kaynak dildeki metnin anlaşılması; kelimelerin değil, anlamın aktarımı; anlamsal seviyelerin ayırt edilebilmesi (düz anlam - yan anlam); bütünlük - parça ilişkisinin değerlendirilmesi (metnin bütünlüğünün önemi); hedef metnin tutarlılığı bulunmaktadır (1990, s. 199). 
Çevirmenin uygulayabildiği teknikler arasında ise sözcüksel birimlerin yerlerinin değiştirilmesi (kaynak metindeki birimlerin hedef dildeki metnin başka bir kısmına kaydırılması); sözcüksel eklemeler (kaynak metindeki gizli bilgilerin hedef metinde açık bir şekilde yapılandırılması); çıarımlar (hedef metinde fazlalığı oluşturacak sözcüksel birimlerden vazgeçme) gibi tekniklerden söz edilmektedir (Komissarov, 1990, s. 204).

\section{Sonuç}

Rusya'daki çeviri kuramı 1930'lu yıllarda edebi metinlerin çevirilerinin değerlendirilmesindeki öznel 'estetik' kriterlerin yerine nesnel ve bilimsel normları oluşturma çabalarından doğsa da kısa bir süre içinde edebiyat biliminden uzaklaşıp çeviri sürecinde ortaya çıkan sorunları ve çevirinin sonucunda oluşan hedef metin ile kaynak metin arasındaki dilsel ilişkileri inceleyen dilbilimsel araştırma alanı olarak gelişmeye başlamıştır. İlk başta çeviri sürecindeki dilsel dönüşümler üzerinde odaklanan çeviri araştırmaları dilbilim alanındaki gelişmeleri takip etmiştir. Bu anlamda Rusya'daki çeviri kuramında çeviri olgusuna yönelik yapısal, işlevsel, anlamsal, göstergebilimsel yaklaşımların uygulandığı farklı kuramsal eğilimlerin geliştirildiği görülebilir. Böylece tek bir çeviri kuramından değil, çeviri olgusuna yönelik farklı dilbilimsel yaklaşımları uygulayan çeviri kuramlarından söz etmek daha doğru olabilir.

Rusya'daki çeviri kuramının diğer bir özelliği, kuramsal yaklaşımların deneyimli çevirmenler olan akademisyenler tarafından geliştirilmesidir. Bu anlamda çeviri kuramı ile çeviri uygulamaları arasında kopukluğun olmadığı, kuramsal yaklaşımların gerçek çevrilmiş metinlere dayanarak geliştirildiğini söylemek gerekir. Bunun yanı sıra her akademisyen belli bir dil çiftinde uzman olduğu için kuramsal yaklaşımların ve uygulamaların belli bir dil çiftine yönelik geliştiği görülebilir. Böylece başta Avrupa dilleri olmak üzere farklı dil çiftlerine yönelik çeviri sürecindeki sorunların ve çeviri stratejilerinin betimlemeleri ve sınıflandırmaları ortaya çıkmıştır.

Dil çiftine yönelik çeviri uygulamalarının yanı sıra özel amaçlı olarak nitelenebilen çeviri uygulamaları da geliştirilmiştir. Özel amaçlı çeviri uygulamaları iktisat, hukuk, ticaret, kitle iletişim araçları, diplomasi, askeri, teknik, insani gibi farklı bilgi alanlarını kapsamıştır. Bu kez çeviri sorunları ve çeviri stratejileri metnin türüne ve konusuna göre çözümlenmiş ve sınıflandırılmıştır. Gerek dil çiftine yönelik gerekse özel amaçlı çeviri uygulamaları çeviri eğitiminde akademik ders kitapları biçiminde somutlaşmıştır.

\section{Kaynakça}

Barhudarov, L. (1975). Yazık i Perevod. Voprosı Obşçey i Çastnoy Teorii Perevoda. Moskova: Mejdunarodnıye Otnoşeniya.

Çukovskiy, K. (1919). Perevodı Prozaiçeskiye. Printsıpı Hudojestvennogo Perevoda. Peterburg: Vsemirnaya Literatura.

Fedorov, A. (2002). Osnovı Obşçey Teorii Perevoda (Lingvistiçeskiye Problemı). Moskova: Filologiya Tri.

Gak, V. (1962). Kurs Perevoda. Frantsuzskiy Yazık Obşçestvenno-Politiçeskaya Leksika. Moskova: İMO.

Gak, V. (2000). Teoriya i Praktika Perevoda. Frantsuzkiy Yazık. Moskova: İnterdialekt.

Komissarov, V. (1990). Teoriya Perevoda (Lingvistiçeskiye Aspektr). Moskova: Vış̧aya Şkola.

Komissarov, V. (2002). Lingvistiçeskoye Perevodovedeniye $v$ Rossii. Moskova: ETS. 
Kozan, O. (2016). Yabancı Dil/Çeviri Eğitiminde İşlevsel Söz Dizimi Kuramı: Türkçe-Rusça Dil Çifti Örneği. İçinde A. Kaşoğlu (Ed.), Prof. Dr. Altan Aykut’a Armağan. Rus Dili ve Edebiyatının İzinde, s. 259-281.

Kozan, O. (2017). Sovyet Döneminde Edebi Çeviri Kuramının Doğuşu. İçinde A. Kaşoğlu (Ed.), Liderlerin Sovyeti. Devrimden Perestroykaya, s. 314-327.

Kozan, O. (2018). Anlamsal Bilgilerin Dilde Kodlanması: Türkçe-Rusça Dil Çiftinde Eylem $\rightarrow$ Fiil. Dil Dergisi, 170 (1), s. 54-72.

Kozan, O. (2019). Yabancı Dil/Çeviri Eğitimi Açısından Dil Dünya Görüşü Kavramı ve Nesnelerin Adlandırılması (Türkçe-Rusça Dil Çifti). Dil Dergisi, 169 (2), s. 151-167.

Minyar-Beloruçev, R. (1996). Teoriya i Metodı Perevoda. Moskova: Moskovskiy Litsey.

Nelyubin, L., Huhuni, G. (2003). İstoriya i Teoriya Perevoda v Rossii. Moskova: MGOU.

Prunč, E. (2015). Puti Razvitiya Zapadnogo Perevodovedeniya. Moskova: R. Valent.

Retsker, Y. (2010). Teoriya Perevoda i Perevodçeskaya Praktika. Moskova: Valent.

Şveytser, A. (1973). Perevod i Lingvistika. O Gazetno-İnformatsionnom i Voenno-Publitsıstiçeskom Perevode. Moskova: Voennoye İzdatelstvo Ministerstva Oboronı.

Şveytser, A. (1988). Teoriya Perevoda: Status, Problemı, Aspektı. Moskova: Nauka. 